Page $25-42$

\title{
RELIGIOSITY AND ISLAMIC BANKING PRODUCT DECISION: SURVEY ON EMPLOYEES OF PT TELEKOMUNIKASI INDONESIA
}

\author{
Abdul Mukti Soma, Ina Primiana, Sudarso K. Wiryono, Erie Febrian \\ Universitas Padjajaran, Institut Teknologi Bandung \\ muktisoma@gmail.com; ina.primiana@fe.unpad.ac.id; sudarso_kw@sbm-itb.ac.id; \\ erie_febrian@fe.unpad.ac.id
}

\begin{abstract}
.
The objective of this research is to examine the religiosity on Islamic banking product decision. A survey method was employed using a sample of 2.627 employees at different level of education, level of income, gender, age, marital status, length of service, work location (provincial based), ownership of conventional banking products as well as ownership of sharia banking products among employees of PT. Telekomunikasi Indonesia. The study also developed valid and reliable scales for religiosity and selection of sharia banking product. The findings of the study revealed that dimensions of religiosity affected understanding of Islamic Banking Concept and also affected Bank Selection Criteria. Future research is required to investigate private employees and semi government employees, even in military institutions to find different figure of religiosity and preference of sharia banking products, by identifying the specific areas of religiosity that have particular impact in determining the sharia banking products.
\end{abstract}

Keywords: religiosity, conventional banking products, Islamic banking products, financial awareness.

\begin{abstract}
Abstrak.
Penelitian ini bertujuan untuk menguji tingkat religiusitas terbadap keputusan pemiliban produk bank syariah. Sebuah metode survei dengan menggunakan sampel dari 2,627 karyawan di tingkat pendidikan yang berbeda, tingkat pendapatan, jenis kelamin, usia, status perkawinan, masa kerja, lokasi kerja (provinsi berdasarkan), kepemilikan produk perbankan konvensional serta kepemilikan syariah produk. perbankan di lingkungan karyawan PT. Telekomunikasi Indonesia. Penelitian ini juga mengembangkan skala yang valid dan dapat diandalkan untuk religiusitas dan pemilihan produk perbankan syariah. Temuan-temuan dari penelitian sebelumnya menunjukkan bahwa dimensi religiusitas dipengarubi oleh pemahaman Konsep Perbankan Islam dan juga dipengarubi Kriteria Seleksi Bank. Penelitian di masa depan diperlukan untuk. meneliti pegawai swasta dan pegawai semi pemerintah (seperti balnya pegawai Badan Usaba Milik Negara), babkan di lembaga militer untuk menemukan sosok yang berbeda dari religiusitas dan preferensi produk perbankan syariah, dengan mengidentifikasi area religiusitas spesifik yang memiliki dampak tertentu dalam menentukan pilihan produk perbankan syariah.
\end{abstract}

Kata Kunci: religiusitas, produk perbankan konvensional, produk perbankan syariah, kesadaran keuangan.

Received: November 30, 2016; Revised: January 3, 2017; Approved: January 10, 2017 
Religiosity and Islamic Banking Product

A. Mukti Soma, Ina Primiana, Sudarso K Wiryono, Erie Febrian

\section{INTRODUCTION}

One of the basic characteristics of an Islamic economic system is that it is free of riba or usury or interest rate. The Arabic word riba means an increase in or addition to, but in practice riba refers to the additional amount, in excess of the principal, that a lender charges a borrower. The riba systems were practiced in the money lending and barter trade activities even in the pre-Islamic period. During this period whenever a person borrowed money from a lender, the borrower asked the lender to extend the period of payment and in return the borrower had to pay the lender a fixed amount of money in excess of the principal. At the time of the revelations of the Qur'an on riba, there existed many forms of riba. For example, when a person sold an item the buyer would be made aware of the period of payment. When the buyer failed to make repayment within this specified period, he was given more time to make the payment but the lender charged the borrower an additional amount. And in the case of lending money, the lender asked the borrower to repay the principal together with an additional amount of money within a specified period of time.

The Qur'an and hadith do not specifically define riba and therefore there have been different views among the Islamic scholars on the concept of riba. Fortunately, there are a number of verses in the Qur'an and hadith, which are related to riba. These two sources of reference help Moslem scholars to explain the concept of riba. Specifically, Allah says:

"Those who devour usury will not stand except as stands as one whom the Evil One by his touch hath driven to madness. That is because they say: "Trade is like usury," but God hath permitted trade and forbidden usury. Those who after receiving direction from their Lord, desist, shall be pardoned for the past; their case is for God (to judge); but those who repeat (the offence) are companions of the fire: they will abide therein (forever). Surah Al-Baqarah (2): 275.

The Prophet condemned not only those who took riba but also those who gave riba and those who recorded or witnessed the transaction involving riba, reminded the Moslems that these people were all committing sins. The Prophet (PBUH) explained in his hadith that riba existed in cash loans, money transactions, and in barter trade whenever one party received excess over and above the commodity being exchanged. The Prophet (PBUH) says:

"Every form of riba is cancelled; principal indeed is yours which ye shall have; wrong not and you shall not be wronged. God has given His injunctions that interest is totally forbidden. I first start with interest (which people owe) to my uncle Abbas and declared it all cancelled." He then on bebalf of his uncle cancelled the total amount of riba due on his loan from his debtors. 
Thus, the essence of riba is the excess, whether it is in the commodity exchange or in money exchange such as when one dinar is exchanged for two dinars. In the case of a barter trade, which is an exchange of goods for goods, riba is committed when more of one commodity is exchanged for exactly similar commodity. Islamic Banking is growing rapidly in various parts of the globe. Islamic banking initially established to cater for the needs of Moslems customers, as Moslems are obliged to obey the Sharia principles (Islamic Jurisprudence) in all aspects of life. It is argued that Moslems patronize Islamic banking due to religious consideration however; it is not clear why the non-Moslems patronize Islamic banking.

Islamic banks operate worldwide in over 75 countries mostly in Middle East and Southeast Asia, with Bahrain and Malaysia as the biggest hubs. Islamic banking has established itself as a choice of banking alongside the conventional interest-based banking, and it has been expanding rapidly over the last two decades in both Moslem and nonMoslem countries. As it is expanding from its niche, the Islamic banking industry is becoming a market that could rival the conventional sector in many countries. Dusuki and Abdullah (2006) described Islamic banking as no longer a business entity operated only to fulfill the religious obligations of the Moslem community, but more significantly, it is striving to fulfill the needs and demands of new customers as well.

The distinguishing feature of an Islamic banking from its counterpart, the conventional banking, is that it is free of riba. Islam prohibits Moslems from taking as well as giving riba. The prohibition of riba is mentioned in four different revelations in the Qur'an. The first revelation clarifies that charging interest is equivalent to taking away the wealth of Allah from a person; the second revelation condemns it since riba is a wrongful appropriation of wealth belonging to others. The third revelation asks all Moslems to avoid riba altogether. The fourth revelation makes a clear distinction between interest and trade, asking Moslems to take only the principal and even forgo this principal if a borrower is unable to repay the loan. The Qur'an warns those who disobey the prohibition of riba that they are actually at war with God and His Prophet (PBUH).

It has been argued that profit rate helps to allocate resources efficiently. As the profit rate determined by market forces therefore capital will flow into the sectors, which offer the highest profit rate. The owner of capital may invest his capital by giving it to an entrepreneur with a viable economic project, idea, expertise, and experience and use the capital for production activities and they are permitted to share the profits between them. 
Religiosity and Islamic Banking Product

A. Mukti Soma, Ina Primiana, Sudarso K Wiryono, Erie Febrian

In the case of losses, it will be borne wholly by the owner of capital. This type of financing is termed as mudarabah and it was practiced even in the pre-Qur'an days. Another legitimate form of financing in Islam is based on equity participation termed as musharakah when the partners use their capital jointly to generate economic activities. Profits or losses will be shared between the partners according to the agreed upon formula based on the equity ratio.

Mudarabah and musharakah are the two basic principles of Islamic banking. An Islamic bank provides depository facilities such as saving deposit, current account, and investment deposit and manages the mudarabah funds of the depositors to generate profits subject to the rules of mudarabah. The bank then uses the mudarabah fund of the depositors to extend loans to the borrowers based on mudarabah and other forms of Islamic financing. The bank may choose to enter into musharakah contracts with the borrowers of the funds, sharing profits and losses between them.

Demographic factors such as age; gender, education level, majors and income levels have been found to influence consumer behavior in the marketing of bank/financial services (Phau and Woo, 2008; Worthington, 2006; Dellande and Saporoschenko, 2004; Chen and Volpe, 2002). Besides this, one's socioeconomic and cultural background is also likely to have an impact on an individual's financial knowledge, perception of risk, consumption and spending patterns. In particular, lower level of financial knowledge leads to overestimation of credit ratings, decreased level of savings, budgeting and investment.

The role of Islam has become a key public and political concern in recent years and this development has resulted in a growing interest in Moslem religiosity as the subject of empirical social research. How religious are Moslems? What influence does Moslem piety exert on political opinions? Is Moslem religiosity an obstacle to social integration? There is still little knowledge about Islamic religiosity and its associations with other characteristics of Moslems.

Most research conceptualizes Moslem faith as an inherent monolithic bloc. Thus, Islamic religiosity appears to be a one-dimensional construct. Some studies use indicators that stress different single aspects of Moslem religiosity, e.g. belief in Allah, fasting at Ramadan, or just the religious self-assessment of the respondents. Other studies adopt several indicators, combining them in an additive index (Kecskes 2000). However, the use 
of ever changing indicators to measure an imaginary one-dimensional Moslem religiosity unsurprisingly yields results that differ from study to study and even contradict each other.

Religious commitment plays an important role in people's lives through shaping their beliefs, knowledge, and attitudes. Different religious groups such as Moslems, Christians, Buddhists, and others with other religious orientations have differing beliefs. These beliefs cannot be avoided when a society is analyzed (Fam et al., 2002). These religious commitments and beliefs have influenced the feelings and attitude of people towards consumption (Jamal, 2003). For example, in England, the consumption pattern of the Indian society as compared to the indigenous white British society is different due to commitment to specific communal or religious groups (Lindridge, 2005). Furthermore, it is the religion which specifies prohibited and non-prohibited things which influence the consumer's consumption decision. For example, beef is prohibited in Hinduism while in Islam it is not forbidden. The consumption of pork is prohibited in both Islam and Judaism but it is allowed in Christianity. In effect, religion influences what consumers belief, what they like, and what they dislike (Fam et al., 2002).

Halal products are those that are Sharia compliant, i.e. do not involve: the use of haram (prohibited) ingredients, exploitation of labor or environment, and are not harmful or intended for harmful use. Moslems are obliged by religion to clearly scrutinize products to make sure they are halal. And, they are strongly encouraged by the Islamic teachings to shy away from consumables that are doubted.

Previous studies on perceptions of Islamic banking customers can be categorized into four. The first category is studies on perception towards Islamic banking that have been conducted in either predominantly Moslem countries such as Pakistan or predominantly non-Moslem countries such as Singapore. The second group of studies has focused on Islamic banking customer in general without separating them by religious affiliations such as Moslems and non-Moslem. The third category is a comparative study on customers of Islamic and conventional banking. The final category that has relation to the present studies conducted on non-Moslem customers of Islamic banking. Yet, we will elaborate much more on Islamic in Islamic state or in the country with Moslem as majority.

Previous studies acted as an indicator to determine customers' perception towards Islamic banking. For instance, Hassan (2007) studied customers' perception towards Islamic banking in Pakistan. His study examined several important dimensions including 
Religiosity and Islamic Banking Product

A. Mukti Soma, Ina Primiana, Sudarso K Wiryono, Erie Febrian

knowledge, socio-religious context, Sharia compliances, and willingness to deal with Islamic banks, and quality and attractiveness of offerings. This study found a positive perception of all dimensions investigated with customers indicating overall high satisfaction towards products and services of Islamic banks as compared to conventional banks.

Rashid, et.al (2008) conducted a study on perception of customers towards domestic Islamic banks in Bangladesh. They examined six critical elements, namely corporate efficiency, compliance with Islamic rules, convenience, core banking, confidence, and cost benefit. This study found that customers are highly satisfied with corporate efficiency and compliance with Islamic rules as substantial factors for them to choose their intended service. In the case of Malaysia, Dusuki and Abdullah (2006) studied several critical reasons why Malaysian customers patronize Islamic banks and measured the elements of reputation, service delivery, product price, and social responsibility of Islamic banks. The study found that a combination of Islamic and financial reputation and service quality are the main patronage factors.

Specifically, among corporate customers, Ahmad and Haron (2002) conducted a study to examine their perception towards Islamic banking in Malaysia. They examined factors such as the usage of banking facilities, respondents' understanding of Islamic banking concept and practices, and personal opinions towards Islamic banking. They found that cost of the products and services is the most important factor perceived by corporate customers in selecting their banks. Similarly, Rustam et.al. (2011) discussed three main parameters to determine the perception of corporate customers towards Islamic banking in Pakistan. They examined factors such as the usage of conventional and Islamic banking facilities, respondents' understanding of Islamic banking system, and their personal opinion on various aspects of Islamic banking products like economic and religious view. They found that the Islamic banking industry has good potential within the Pakistani corporate sector.

Respondents from a country with predominantly Moslems showed a good understanding on Islamic banking influence Islamic banks selection. Bley and Kuehn (2004) studied the perception and knowledge of students towards Islamic banking in UAE. They tested hypotheses on lack of basic Islamic product knowledge, aspect of religion, and cultural differences to determine students' perception towards the Islamic financial system. Language barriers prevented students from learning the Islamic financial system, but 
students with good academic achievement showed a good understanding of Islamic banking concepts.

In Pakistan and Bangladesh, studies showed that people possessed a good understanding of Islamic banking concepts. Hassan (2007) conducted a research on understanding of Pakistanis towards Islamic banking and found 90\% of respondents understood Islamic banking terms such as 'riba'. Some studies have suggested that customers choose Islamic banks mainly on religious grounds. Thus, customers in Islamic banks seriously consider whether the bank complies with Sharia rules in all stages of banking activities (Haron et al., 1994; Ahmad \& Haron, 2002). The variables deemed important under religious (Islamic) construct that include compliance to Sharia rules, offerings of Sharia compliant services, and offering interest free loans, among others. Rashid et.al (2008) found compliance to Sharia law is one of influential factor for banking selection among customers in Bangladesh.

Studies on religious issue as banking selection criteria showed different findings as it perceived to be the most important criteria especially among Moslems, while not to nonMoslems. Some studies showed religious issues as not to be the most important factor of banking selection. Bley and Kuehn (2004) found that among Moslems in UAE the preference for Islamic banking was primarily driven by religious beliefs, not financial knowledge. That is, the stronger the religious commitment, the greater preference for Islamic banking services. Consequently, a study conducted by Dusuki and Abdullah (2007) in Malaysia found that religious factor is not the main criteria for banking selection. They found that competent and knowledgeable personnel, followed by friendly personnel and service quality as their main patronage factors.

Although the religious dimension plays an important role in banking selection, quality and attractiveness of offerings is also perceived as significantly important for the customers to patronize Islamic banking. Since some previous research indicated that religion is no longer the main factor in attracting customers, Islamic banks should recognize that customers view them just like any other commercial bank. Thus the quality of service and the products and services offered must be comparable with those offered by the commercial banks.

Rashid et.al. (2008) found the higher demand of Islamic banking products and services requires existence of superior quality in service, beside the efficiency in system, strict compliance to Sharia and satisfactory community service through job creation and 
Religiosity and Islamic Banking Product

A. Mukti Soma, Ina Primiana, Sudarso K Wiryono, Erie Febrian

ensuring consistency in service provisions. The study further demonstrated that faster transaction system, less cost of banking, and efficient counter management can add value to everyday volume of transactions and simultaneously increase customer satisfaction. Rustam et al. (2011) argued that majority of them perceived both religion and economics as the patronage factors in Islamic bank selection. This particular study showed that factors such as cost and benefit to the company, quality of service delivery, size and reputation of the bank, convenience, and friendliness of bank personnel were considered critical for bank selection.

Rashid et al. (2008) conducted a study on the prospect and growth potentials of Islamic banks in Bangladesh from both Islamic and conventional bankers' perspective. They found that conventional bankers believe that Islamic banks only claim but do not actually follow the true Sharia based system of banking. For them, the conventional system of banking is more lucrative and it stands as an honest method of banking as opposed to Islamic banking, which they feel is only profitable as a Strategic Business Unit (SBU). In contrast, Islamic bankers endorse the view of risk minimization by zero interest rates, while conventional banks do not reinforce this claim. However, Islamic bankers believed that Islamic banks in Bangladesh have a greater social and moral motive to fulfill, even at the expense of reduced profit.

\section{METHOD}

The aim of this study is to investigate whether "Dimensions of Religiosity become Determinants In the selection of Islamic Banking Products". Study was conducted among employees of PT. Telekomunikasi Indonesia (Telkom) spread over Indonesia at different level of education, level of income, gender, age, marital status, length of service, ownership of conventional banking products as well as ownership of sharia banking products.

The study was conducted through an online survey to all Moslem employees scattered in different regions and with diverse demographic characteristics. From a total of 14.651 Moslem employees (the population), 2,627 respondents answered the questionnaire. 91 respondents were removed since the answers were incomplete. Then we processed the data by applying MSI (Method of Successive Intervals) and path analysis. 
Table 1. Demographics Recapitulation

\begin{tabular}{|c|c|c|c|}
\hline CHARACTERISTICS & CRITERIA & FREQUENCY & PERCENTAGE \\
\hline \multirow[t]{3}{*}{ Division } & Operational & 2252 & 88.8 \\
\hline & Non Operational & 284 & 11.2 \\
\hline & Total & 2536 & 100.0 \\
\hline \multirow[t]{3}{*}{ Gender } & Female & 348 & 13.7 \\
\hline & Male & 2188 & 86.3 \\
\hline & Total & 2536 & 100.0 \\
\hline \multirow[t]{8}{*}{ Age } & $20-25$ years & 12 & .5 \\
\hline & $25-30$ years & 59 & 2.3 \\
\hline & $31-35$ years & 38 & 1.5 \\
\hline & $36-40$ years & 36 & 1.4 \\
\hline & $41-45$ years & 387 & 15.3 \\
\hline & $46-50$ years & 556 & 21.9 \\
\hline & $>50$ years & 1448 & 57.1 \\
\hline & Total & 2536 & 100.0 \\
\hline \multirow[t]{3}{*}{ Marital Status } & Married & 2483 & 97.9 \\
\hline & Single & 53 & 2.1 \\
\hline & Total & 2536 & 100.0 \\
\hline \multirow[t]{6}{*}{ Level of Education } & High School & 869 & 34.3 \\
\hline & Diploma & 627 & 24.7 \\
\hline & Undergraduate & 850 & 33.5 \\
\hline & Graduate & 186 & 7.3 \\
\hline & Doctoral & 4 & .2 \\
\hline & Total & 2536 & 100.0 \\
\hline \multirow[t]{6}{*}{ Length of Services } & $<5$ years & 33 & 1.3 \\
\hline & $6-10$ years & 55 & 2.2 \\
\hline & $11-15$ years & 93 & 3.7 \\
\hline & $16-20$ years & 477 & 18.8 \\
\hline & $>20$ years & 1878 & 74.1 \\
\hline & Total & 2536 & 100.0 \\
\hline \multirow[t]{6}{*}{ Monthly Income } & $<$ USD 800 & 1730 & 68.2 \\
\hline & USD $800-1,600$ & 689 & 27.2 \\
\hline & USD $1,600-2,400$ & 83 & 3.3 \\
\hline & USD 2,400 - 3,200 & 16 & .6 \\
\hline & $>$ USD 3,200 & 18 & .7 \\
\hline & Total & 2536 & 100.0 \\
\hline Conventional & Ever and still & 2077 & 81.9 \\
\hline \multirow[t]{4}{*}{ Customers } & Ever and stop & 120 & 4.7 \\
\hline & Never/Not Yet & 331 & 13.1 \\
\hline & Not Yet and eager to & 8 & 0.3 \\
\hline & Total & 2536 & 100.0 \\
\hline \multirow[t]{5}{*}{ Sharia Bank Customers } & Ever and still & 1051 & 41.4 \\
\hline & Ever and stop & 348 & 13.7 \\
\hline & Never/Not Yet & 1057 & 41.7 \\
\hline & Not Yet and eager to & 80 & 3.2 \\
\hline & Total & 2536 & 100.0 \\
\hline
\end{tabular}


In this research we tried to find whether there was a correlation between Dimensions of Religiosity and Sharia Banking Service Selection. We developed Islamic Religiosity Index by Shabbir as follows: Ideological dimension/belief $\left(\mathrm{X}_{1}\right)$, Ritual Dimension $/ \mathrm{X}_{2}$, Intellectual Dimension $/ \mathrm{X}_{3}$, Conceptual Dimension $/ \mathrm{X}_{4}$, and Experiential Dimension $/ \mathrm{X}_{5}$, as cause variables. While the result variables were Sharia Banking Services, which consisted of Islamic Banking Concept $\left(\mathrm{Y}_{1}\right)$ and Bank Selection Criteria/ $\mathrm{Y}_{2}$

\section{RESULT AND DISCUSSION}

The correlation coefficient between the cause variables $\mathrm{X}_{1}, \mathrm{X}_{2}, \mathrm{X}_{3}, \mathrm{X}_{4}$ and $\mathrm{X}_{5}$ to the result variable $Y_{1}$ are shown in the following Table 2. These results indicated that there were significant positive relationship among the cause variables of $\mathrm{X}_{1}, \mathrm{X}_{2}, \mathrm{X}_{3}, \mathrm{X}_{4}$ and $\mathrm{X}_{5}$ with result variable $Y_{1}$ indicated by the positive correlation coefficient with significance level $\alpha=$ less than 0.05 . The strongest linkage between result variables $Y_{1}$ and the cause variables is demonstrated by the relationship between $X_{5}$ and $Y_{1}$ with a correlation coefficient of $\mathrm{r}=0.437$; while the weakest relationship is shown by the relationship between $\mathrm{X}_{1}$ and $\mathrm{Y}_{1}$ with a correlation coefficient of $\mathrm{r}=0.338$.

Table 2. Correlations amongst variables

\begin{tabular}{lrrrrrrr}
\hline & & $\mathrm{Y}_{1}$ & $\mathrm{X}_{1}$ & $\mathrm{X}_{2}$ & $\mathrm{X}_{3}$ & $\mathrm{X}_{4}$ & $\mathrm{X}_{5}$ \\
\hline Pearson & $\mathrm{Y}_{1}$ & 1.000 &. $\mathbf{3 3 8}$ & $\mathbf{. 3 4 3}$ & $\mathbf{. 3 6 7}$ & $\mathbf{. 4 3 5}$ & $\mathbf{. 4 3 7}$ \\
Correlation & $\mathrm{X}_{1}$ & .338 & 1.000 & .762 & .732 & .628 & .532 \\
& $\mathrm{X}_{2}$ & .343 & .762 & 1.000 & .801 & .695 & .570 \\
& $\mathrm{X}_{3}$ & .367 & .732 & .801 & 1.000 & .750 & .600 \\
& $\mathrm{X}_{4}$ & .435 & .628 & .695 & .750 & 1.000 & .650 \\
& $\mathrm{X}_{5}$ & .437 & .532 & .570 & .600 & .650 & 1.000 \\
Sig. (1-tailed) & $\mathrm{Y}_{1}$ &. & .000 & .000 & .000 & .000 & .000 \\
& $\mathrm{X}_{1}$ & .000 &. & .000 & .000 & .000 & .000 \\
& $\mathrm{X}_{2}$ & .000 & .000 &. & .000 & .000 & .000 \\
& $\mathrm{X}_{3}$ & .000 & .000 & .000 &. & .000 & .000 \\
& $\mathrm{X}_{4}$ & .000 & .000 & .000 & .000 &. & .000 \\
& $\mathrm{X}_{5}$ & .000 & .000 & .000 & .000 & .000 &. \\
\hline
\end{tabular}

By applying the backward method we obtained three (3) models, in the first model all of the cause variables included in the model of path analysis equation, then in the second model causes variable $\mathrm{X}_{3}$ was excluded from the path analysis equation model, and in the third model by removing the cause variable $\mathrm{X}_{2}$ from the path analysis equation model. 
Table 3. Simultaneous Correlation Coefficient and Coefficient of Determination of Cause Variables to the result variable $\mathrm{Y}_{1}$

\begin{tabular}{rrc}
\hline Model & R & R Square \\
\hline 1 & $.482(\mathrm{a})$ & .233 \\
2 & $.482(\mathrm{~b})$ & .233 \\
3 & $.482(\mathrm{c})$ & .232 \\
\hline
\end{tabular}

Predictors: (Constant), $\mathrm{X}_{5}, \mathrm{X}_{1}, \mathrm{X}_{4}, \mathrm{X}_{2}, \mathrm{X}_{3}$

b Predictors: (Constant), $\mathrm{X}_{5}, \mathrm{X}_{1}, \mathrm{X}_{4}, \mathrm{X}_{2}$

c Predictors: (Constant), $\mathrm{X}_{5}, \mathrm{X}_{1}, \mathrm{X}_{4}$

The results of Hypotheses test on the effect of $\mathrm{X}_{1}, \mathrm{X}_{4}, \mathrm{X}_{2}, \mathrm{X}_{3}$ and $\mathrm{X}_{5}$ to $\mathrm{Y}_{1}$ can be determined simultaneously by testing the significance of the simultaneous correlation coefficient and the coefficient of determination by using $\mathrm{F}$ as shown in the following ANOVA table.

Table 4. Effect of Cause Variables to Result Variable $\mathbf{Y}_{1}$

\begin{tabular}{clrrrrl}
\hline Model & & Sum of Squares & \multicolumn{1}{c}{ df } & \multicolumn{1}{c}{ Mean } \\
Square & F & Sig. \\
\hline 1 & Regression & 26001.673 & 5 & 5200.335 & 153.362 & $.000(\mathrm{a})$ \\
& Residual & 85789.532 & 2530 & 33.909 & & \\
& Total & 111791.205 & 2535 & & & \\
2 & Regression & 26001.652 & 4 & 6500.413 & 191.778 & $.000(\mathrm{~b})$ \\
& Residual & 85789.554 & 2531 & 33.896 & & \\
& Total & 111791.205 & 2535 & & & \\
& Regression & 25984.460 & 3 & 8661.487 & 255.585 & $.000(\mathrm{c})$ \\
& Residual & 85806.745 & 2532 & 33.889 & & \\
& Total & 111791.205 & 2535 & & & \\
\hline
\end{tabular}

Predictors: (Constant), $\mathrm{X}_{5}, \mathrm{X}_{1}, \mathrm{X}_{4}, \mathrm{X}_{2}, \mathrm{X}_{3}$

b Predictors: (Constant), $\mathrm{X}_{5}, \mathrm{X}_{1}, \mathrm{X}_{4}, \mathrm{X}_{2}$

c Predictors: (Constant), $\mathrm{X}_{5}, \mathrm{X}_{1}, \mathrm{X}_{4}$

d Dependent Variable: $\mathrm{Y}_{1}$

This Table 4 shows that all of the path analysis equation models (model 1, model 2 and model 3) had significance levels less than $\alpha=0.05$. This suggested that research Hypotheses "there are significant variables X1, X2, X3, X4 and X5 affected Y1 simultaneously" can be accepted (indicated by Model 1), or in other words, cause variables $\mathrm{X} 1, \mathrm{X} 2, \mathrm{X} 3, \mathrm{X} 4$ and X5 showed simultaneous significant effect to Y1. Hypotheses test on the partial effect of $\mathrm{X} 1, \mathrm{X} 2, \mathrm{X} 3, \mathrm{X} 4$ and $\mathrm{X} 5$ to $\mathrm{Y} 1$ by using the $\mathrm{t}$ test; the results are shown in the following table.

The results of calculations based on the path analysis of this table is the following path analysis equation model 
Model 1: $\mathrm{Y}_{1}=0.065 \mathrm{X}_{1}-0.022 \mathrm{X}_{2}+0.001 \mathrm{X}_{3}+0.241 \mathrm{X}_{4}+0.258 \mathrm{X}_{5}$

Based on the significance of the correlation coefficient, it is shown that the value of the correlation coefficient significance X2 and X3 which was 0.509 and 0.980 had larger values than 0.05 ; which showed that in partial, cause variable $\mathrm{X} 2$ and $\mathrm{X} 3$ had no significant effect on the result variable Y1. To obtain the best equation model using backward method, the next step is to exclude the least significant cause variable to the result variable Y1, which was cause variable X3, then we obtained the model 2 .

Model 2: $\mathrm{Y} 1=0.066 \mathrm{X}_{1}-0.021 \mathrm{X}_{2}+0.241 \mathrm{X}_{4}+0.258 \mathrm{X}_{5}$

Table 5. Path coefficients and Test of the Influence Cause Variables

\begin{tabular}{cccrc}
\hline Model & Cause Variables & Path Coefficient & \multicolumn{1}{c}{$\mathbf{t}$} & Sig. \\
\hline 1 & $\mathrm{X}_{1}$ & .065 & 2.294 & .022 \\
& $\mathrm{X}_{2}$ & -.022 & -.660 & .509 \\
& $\mathrm{X}_{3}$ & .001 & .025 & .980 \\
& $\mathrm{X}_{4}$ & .241 & 8.304 & .000 \\
& $\mathrm{X}_{5}$ & .258 & 10.886 & .000 \\
2 & $\mathrm{X}_{1}$ & .066 & 2.370 & .018 \\
& $\mathrm{X}_{2}$ & -.021 & -.712 & .476 \\
& $\mathrm{X}_{4}$ & .241 & 8.886 & .000 \\
& $\mathrm{X}_{5}$ & .258 & 10.943 & .000 \\
3 & $\mathrm{X}_{1}$ & .054 & 2.381 & .017 \\
& $\mathrm{X}_{4}$ & .234 & 9.192 & .000 \\
& $\mathrm{X}_{5}$ & .256 & 10.938 & .000 \\
\hline
\end{tabular}

Based on the significance of the correlation coefficient, it is shown that the value of the correlation coefficient significance X2 was 0.476 which had a larger value than $\alpha=$ 0.05; which showed that in partial cause variable $\mathrm{X} 2 \mathrm{had}$ no significant effect on the result variable Y1. To obtain the best equation model using backward method, the next step was to exclude a cause variable, which was not significant to result variable Y1, then we obtained the model 3 .

Model 3: $\mathrm{Y}_{1}=0.054 \mathrm{X}_{1}+0.234 \mathrm{X}_{4}+0.256 \mathrm{X}_{5}$

Based on the significance values of the correlation coefficient, we conclude that the cause variables in this model had significant value smaller than $\alpha=0.05$; which showed that in partial cause variables of $\mathrm{X}_{1}, \mathrm{X}_{4}$ and $\mathrm{X}_{5}$ had a significant partial effect to result variable $\mathrm{Y}_{1}$. The results of Hypotheses test on the influence of the cause variables $\mathrm{X}_{1}, \mathrm{X}_{2}$, $\mathrm{X}_{3}, \mathrm{X}_{4}$, and $\mathrm{X}_{5}$ to result variable $\mathrm{Y}_{1}$ partially showed that only the variables $\mathrm{X}_{1}, \mathrm{X}_{4}$, and $\mathrm{X}_{5}$ had significant partial effects to result variable $Y_{1}$. 
These results indicate that there were significant positive relationships among the cause variables of $\mathrm{X} 1, \mathrm{X} 2, \mathrm{X} 3, \mathrm{X} 4$ and $\mathrm{X} 5$ with result variable $\mathrm{Y} 2$ indicated by the positive correlation coefficient with significance level less than $\alpha=0.05$. The strongest linkage between cause variables and result variable $\mathrm{Y} 2$ is shown by the relationship between $\mathrm{X} 5$ and Y2 with a correlation coefficient of $\mathrm{r}=0.351$; while the weakest relationship is shown by the relationship between the $\mathrm{X} 3$ and $\mathrm{Y} 2$ with a correlation coefficient of $\mathrm{r}=$ 0.273 .

Hypotheses test, either simultaneous using the $\mathrm{F}$ test and partially by using the $\mathrm{t}$ test was performed by applying the backward method, to obtain the best path analysis equation model, by excluding the least significant cause variable one by one until we found entire cause variables affected partially to the result variable.

Table 6. Correlations among cause variables $X_{1}, X_{2}, X_{3}, X_{4}, X_{5}$ to result variable $Y_{2}$

\begin{tabular}{lrrrrrrr}
\hline & & \multicolumn{1}{c}{$\mathrm{Y}_{2}$} & \multicolumn{1}{c}{$\mathrm{X}_{1}$} & \multicolumn{1}{c}{$\mathrm{X}_{2}$} & \multicolumn{1}{c}{$\mathrm{X}_{3}$} & \multicolumn{1}{c}{$\mathrm{X}_{4}$} & \multicolumn{1}{c}{$\mathrm{X}_{5}$} \\
\hline Pearson & $\mathrm{Y}_{2}$ & 1.000 &. $\mathbf{2 8 0}$ &. $\mathbf{2 7 3}$ &. $\mathbf{2 7 3}$ &. $\mathbf{3 4 8}$ & $\mathbf{. 3 5 1}$ \\
& & & & & & & \\
& $\mathrm{X}_{1}$ & .280 & 1.000 & .762 & .732 & .628 & .532 \\
& $\mathrm{X}_{2}$ & .273 & .762 & 1.000 & .801 & .695 & .570 \\
& $\mathrm{X}_{3}$ & .273 & .732 & .801 & 1.000 & .750 & .600 \\
& $\mathrm{X}_{4}$ & .348 & .628 & .695 & .750 & 1.000 & .650 \\
& $\mathrm{X}_{5}$ & .351 & .532 & .570 & .600 & .650 & 1.000 \\
& $\mathrm{Y}_{2}$ &. & .000 & .000 & .000 & .000 & .000 \\
& $\mathrm{X}_{1}$ & .000 &. & .000 & .000 & .000 & .000 \\
& $\mathrm{X}_{2}$ & .000 & .000 &. & .000 & .000 & .000 \\
& $\mathrm{X}_{3}$ & .000 & .000 & .000 &. & .000 & .000 \\
& $\mathrm{X}_{4}$ & .000 & .000 & .000 & .000 &. & .000 \\
& $\mathrm{X}_{5}$ & .000 & .000 & .000 & .000 & .000 & \\
\hline
\end{tabular}

The recapitulation stage test resulted by applying the backward method obtained two (2) models, in the first model all the cause variables included in the path analysis equation model, and then in the second model cause variables X2 were excluded from the path analysis equation model. Coefficient of determination resulted from path analysis are shown in the Table 7.

Table 7. Simultaneous Correlation Coefficient and Coefficient of Determination of Cause Variables to the result variable $\mathbf{Y}_{2}$

\begin{tabular}{llr}
\hline Model & R & \multicolumn{2}{c}{ R Square } \\
\hline 1 & $.390(\mathrm{a})$ & .152 \\
2 & $.390(\mathrm{~b})$ & .152 \\
\hline \multicolumn{3}{c}{ a Predictors: (Constant), $\mathrm{X}_{5}, \mathrm{X}_{1}, \mathrm{X}_{4}, \mathrm{X}_{2}, \mathrm{X}_{3}$} \\
\multicolumn{3}{c}{ b Predictors: (Constant), $\mathrm{X}_{5}, \mathrm{X}_{1}, \mathrm{X}_{4}, \mathrm{X}_{3}$}
\end{tabular}


This table 7 shows that in model 1 , the simultaneous influence of cause variables $\mathrm{X}_{1}, \mathrm{X}_{2}, \mathrm{X}_{3}, \mathrm{X}_{4}$, and $\mathrm{X}_{5}$ to $\mathrm{Y}_{2}$ is equal to $15.2 \%$, and in model 2 the simultaneous influence of cause variables $\mathrm{X}_{1}, \mathrm{X}_{3}, \mathrm{X}_{4}$, and $\mathrm{X}_{5}$ to $\mathrm{Y}_{2}$ is equal to $15.2 \%$. The results of Hypotheses test on the effect of $\mathrm{X}_{1}, \mathrm{X}_{2}, \mathrm{X}_{3}, \mathrm{X}_{4}$ and $\mathrm{X}_{5}$ to $\mathrm{Y}_{2}$ simultaneously can be determined by test the significance of the simultaneous correlation coefficient and the coefficient of determination by using $\mathrm{F}$ as shown in Table 8.

Table 8. The Effect of Cause Variables to Result Variable Y2

\begin{tabular}{cllllll}
\hline Model & & \multicolumn{1}{c}{$\begin{array}{c}\text { Sum of } \\
\text { Squares }\end{array}$} & df & $\begin{array}{c}\text { Mean } \\
\text { Square }\end{array}$ & F & Sig. \\
\hline 1 & Regression & 22797.423 & 5 & 4559.485 & 90.882 & $.000(\mathrm{a})$ \\
& Residual & 126927.907 & 2530 & 50.169 & & \\
& Total & 149725.331 & 2535 & & & \\
2 & Regression & 22796.773 & 4 & 5699.193 & 113.644 & $.000(\mathrm{~b})$ \\
& Residual & 126928.557 & 2531 & 50.150 & & \\
& Total & 149725.331 & 2535 & & & \\
\hline
\end{tabular}

a. Predictors: (Constant), $\mathrm{X}_{5}, \mathrm{X}_{1}, \mathrm{X}_{4}, \mathrm{X}_{2}, \mathrm{X}_{3}$

b. Predictors: (Constant), $\mathrm{X}_{5}, \mathrm{X}_{1}, \mathrm{X}_{4}, \mathrm{X}_{3}$

Dependent Variable: $\mathrm{Y}_{2}$

Table 8 shows that the path analysis equation models, whether model 1 and model 2 had a significance level less than $\alpha=0.05$. This suggests that research Hypotheses "there are significant variables $\mathrm{X}_{1}, \mathrm{X}_{2}, \mathrm{X}_{3}, \mathrm{X}_{4}$ and $\mathrm{X}_{5}$ simultaneously affected to $\mathrm{Y}_{2}$ " can be accepted (indicated by Model 1), or in other words that $\mathrm{X}_{1}, \mathrm{X}_{2}, \mathrm{X}_{3}, \mathrm{X}_{4}$ and $\mathrm{X}_{5}$ showed simultaneous significant effect to $\mathrm{Y}_{2}$. Hypotheses test on the effect of $\mathrm{X}_{1}, \mathrm{X}_{2}, \mathrm{X}_{3}, \mathrm{X}_{4}$ and $\mathrm{X}_{5}$ to $\mathrm{Y}_{2}$ partially by using the $\mathrm{t}$ test, the results are shown in Table 9 .

Tabel 9. Path coefficients and Test the Influence Cause Variables to variable $\mathbf{Y}_{2}$

\begin{tabular}{ccccc}
\hline Model & Cause Variabel & Path coefficient & $\mathbf{t}$ & Sig. \\
\hline 1 & $\mathrm{X}_{1}$ & .096 & 3.192 & .001 \\
& $\mathrm{X}_{2}$ & -.004 & -.114 & .909 \\
& $\mathrm{X}_{3}$ & -.081 & -2.283 & .022 \\
& $\mathrm{X}_{4}$ & .214 & 7.024 & .000 \\
& $\mathrm{X}_{5}$ & .212 & 8.497 & .000 \\
2 & $\mathrm{X}_{1}$ & .094 & 3.432 & .001 \\
& $\mathrm{X}_{3}$ & -.083 & -2.555 & .011 \\
& $\mathrm{X}_{4}$ & .213 & 7.084 & .000 \\
& $\mathrm{X}_{5}$ & .212 & 8.512 & .000 \\
\hline
\end{tabular}

The results of calculations based on the path analysis of this table is the following path analysis equation model 
Model 1: Y2 = 0.096X1 - 0.004X2 - 0.081X3 + 0.214X4 + 0.212X5

Based on the significance of the correlation coefficient, it is shown that the value of the correlation coefficient significance $X_{2}$ which was 0.909 had a larger value than $\alpha=$ 0.05; which shows that in partial, cause variable $\mathrm{X}_{2}$ had no significant effect on the result variable $\mathrm{Y}=$. To obtain the best equation model using backward method, the next step is to exclude the least significant cause variable to the result variable $\mathrm{Y}_{2}$, which was cause variable $\mathrm{X}_{2}$, then we obtained the model 2

Model 2: $\mathrm{Y}_{2}=0.094 \mathrm{X}_{1}-0.083 \mathrm{X}_{3}+0.213 \mathrm{X}_{4}+0.212 \mathrm{X}_{5}$

Based on the correlation coefficient significance values, it is indicated that all of the cause variables in this model had significant value smaller than $\alpha=0.05$; which showed that in partial cause of $\mathrm{X}_{1}, \mathrm{X}_{3}, \mathrm{X}_{4}$ and $\mathrm{X}_{5}$ had a significant partial effect to result variable $\mathrm{Y}_{2}$.

Usman (2015) found that the religious norms have significant affects on the decision in using the Islamic banks. Besides that, he also found that the religious norms among moslems classified into two categories, such as: traditional and contemporary group. Islamic banks also had to increase the satisfaction of customer. Customer satisfaction will increase the loyalty of customer. Suryani and Hendryadi (2015) shown that service quality and communication are dominate factors affecting satisfaction. Cahyani (2016) find that customer satisfaction about service quality in Islamic banks has been above the moderate.

Dayyan (2016) found that the people in Langsa not yet fully trust the operational of Islamic banks. The people think that there is no difference between Islamic banks and conventional banks. Rusydiana (2016) found that there are several problems in Islamic banking industry that need to be resolved. Besides that, other factors that had to consider by Islamic banks is promotion. Al Arif (2010) stated that the promotion cost had an impact on third party funds in Islamic banks.

One strategy that imposed by the policy maker to accelerate the Islamic banking industry is through spin-off policy. According to Bank of Indonesia's survey in 2001, which in this survey said that almost the respondent still had a same thought between Islamic banking and conventional banking. Based on this survey, the spin-off policy established. Al Arif (2014) found that the spin-off policy can had an impact on third party funds in the Indonesian Islamic banking industry. But, the spin-off policy also had an impact on Islamic bank's efficiency. Al Arif (2015) stated that there is a efficiency difference between pre and post spin-off in the Indonesian Islamic banking industry. Miftah and Wibowo (2017) 
Religiosity and Islamic Banking Product

A. Mukti Soma, Ina Primiana, Sudarso K Wiryono, Erie Febrian

offered other strategy, which they research found that another alternatives strategy is through merger.

\section{CONCLUSION}

Based on the results of hypotheses test using path analysis we can conclude that the Ideological dimension/belief $\left(\mathrm{X}_{1}\right)$, Ritual Dimension $\left(\mathrm{X}_{2}\right)$, Intellectual Dimension $\left(\mathrm{X}_{3}\right)$, Conceptual Dimension $\left(\mathrm{X}_{4}\right)$ and Experiential Dimension $\left(\mathrm{X}_{5}\right)$ affected Islamic Banking Concept $\left(\mathrm{Y}_{1}\right)$. Ideological dimension, Conceptual Dimension and Experiential Dimension respectively affected Islamic Banking concept since people with these three "attributes" will always find any idea to enhance their understanding on the phenomenon of Islamic Banking Concept. It is a bit beyond authors' expectation that Intellectual Dimension did not partially affect the Islamic Banking Concept, while ideally people should apply their intellectual to understand the concept.

Based on the results of hypotheses test using path analysis we can conclude that the Ideological dimension/belief $\left(\mathrm{X}_{1}\right)$, Ritual Dimension $\left(\mathrm{X}_{2}\right)$, Intellectual Dimension $\left(\mathrm{X}_{3}\right)$, Conceptual Dimension $\left(\mathrm{X}_{4}\right)$ and Experiential Dimension $\left(\mathrm{X}_{5}\right)$ simultaneously affected Bank Selection Criteria / $\mathrm{Y}_{2}$ significantly (15.2\%). Ideological dimension, Conceptual Dimension, Intellectual Dimension and Experiential Dimension respectively affected Bank Selection Criteria since people with these "attributes" will always find any idea to enhance their understanding to select the most suitable bank to save their money or to make investment. It is - off course - according to authors' expectation that ritual dimension will not partially affect the Bank selection Criteria, since - ideally - people should relate their daily ritual to the selection the bank.

\section{REFERENCES}

Ahmad, N., \& S. Haron. (2002). Perceptions of Malaysian Corporate Customers towards Islamic Banking Products \& Services. International Journal Of Islamic Financial Services, 3(4): 1-14.

Al Arif, M.N.R. (2010). Efektivitas Biaya Promosi dan Biaya Diklat Terhadap Penghimpunan Dana Pihak Ketiga di Bank Syariah (Effectiveness of Promotion Cost and Training-Research Cost on Third Party Funds in Islamic Banks). Jurnal Ilmiah Ekonomi Bisnis. Vol. 15 (3): 175-182.

Al Arif, M.N.R. (2014). Spin-off and It's Impact on The Third Party Funds of Indonesian Islamic Banking Industry. Economic Journal of Emerging Markets. Vol. 6 (1): 50-55. 
Al Arif, M.N.R. (2015). Keterkaitan Kebijakan Pemisahan Terhadap Tingkat Efisiensi Pada Industri Perbankan Syariah di Indonesia (The Relationship Between Spin-off Policy and Efficiency in The Indonesian Islamic Banking Industry). Jurnal Kenangan dan Perbankan. Vol. 19 (2): 295-304.

Bley, J. \& K. Kuehn. (2004). Conventional versus Islamic Finance: Student Knowledge and Perception in the United Arab Emirates. International Journal of Islamic Financial Services, 5(4): 1-13.

Cahyani, P.D. (2016). Tingkat Kepuasan Nasabah Terhadap Kualitas Layanan Perbankan Syariah di Yogyakarta (The Customer Satisfaction to Islamic Banking Service Quality in Yogyakarta). Esensi: Jurnal Bisnis dan Manajemen. Vol. 6 (2): 151-162.

Chen, H. \& R.P. Volpe. (2002). Gender Differences in Personal Fnancial Literacy Among College Students. Financial Services Review, Vol. 11 No. 3: 289-307.

Dayyan, M. (2016) Resistensi Masyarakat Terhadap Perbankan Syariah di Kota Langsa (The People Resistence of Islamic Banks in Langsa City). Esensi: Jurnal Bisnis dan Manajemen. Vol. 6 (2): 247-258.

Dellande, S. \& A. Saporoschenko. (2004). Factors in Gaining Compliance Toward Acceptable Level of Personal Unsecured Debt. The International Journal of Bank Marketing. Vol. 22 No. 4: 279-90.

Dusuki, A. W. \& N.I. Abdullah. (2007). Why do Malaysian Customers Patronize Islamic Banks?. International Journal of Bank Marketing, 25(3): 143-160.

Fam, K.S, D.S. Waller \& B.Z. Erdogan. (2002). The Influence of Religion on Attitudes Towards the Advertising of Controversial Products. European Journal of Marketing, Vol. 38 No. 5: 537-55.

Haron, S., N. Ahmad \& S.L. Planisek. (1994). Bank Patronage Factors of Muslim and NonMuslim Customers. International Journal of Bank Marketing. Vol. 12 (1): 32-40.

Hassan, M. (2007). People's Perceptions towards Islamic Banking. A Fieldwork Study on Bank. Account Holders' Behaviour in Pakistan, 153-176.

Jamal, A. (2003). Marketing in a Multicultural World: The Interplay of Marketing, Ethnicity and Consumption. European Journal of Marketing, Vol. 37 No. 11: 1599-620.

Kecskes, R. (2000). Soziale und identifikative Assimilation türkischer Jugendlicher. Berliner Journal für Soziologie, Vol. 10: 61-78.

Lindridge, A. (2005). Religiosity and The Construction of a Cultural-Consumption Identity. Journal of Consumer Marketing, Vol. 22 No. 3: 142-51. 
Miftah, K. \& H. Wibowo. (2017). Merger and Industrial Acceleration: Study at Indonesian Islamic Banking Industry. Signifikan: Jurnal Ilmu Ekonomi. Vol. 6 (1): 29-48.

Phau, I. \& C. Woo. (2008), Understanding Compulsive Buying Tendencies Among Young Australians: the Roles of Money Attitude and Credit Card Usage. Marketing Intelligence \&o Planning, Vol. 26 No. 5: 441-58.

Rashid, M., M.K. Hassan, \& A. Ahmad. (2008). Quality Perception of the Customers towards Domestic Islamic Banks in Bangladesh. Journal of Islamic Economics, Banking and Finance, 5: 110-131.

Rusydiana, A.S. (2016). Analisis Masalah Pengembangan Perbankan Syariah di Indonesia: Aplikasi Metode Analytic Network Process (The Development Problems Analysis of Islamic Banking in Indonesia: Application of Analytic Network Process Method). Esensi: Jurnal Bisnis dan Manajemen. Vol. 6 (2): 237-246.

Rustam, S., S. Bibi., K. Zaman., A. Rusram. \& U.H.. Zahid. (2011). Perceptions of Corporate Customers Towards Islamic Banking Products and Services in Pakistan. The Romanian Economic Journal, XIV(41): 107-123.

Suryani \& Hendryadi. (2015). A Developing Model of Relationship Between Service Quality, Customer Satisfaction, Loyalty, and Word of Mouth in Islamic Banking. Al-Iqtishad: Journal of Islamic Economics. Vol. 7 (1): 45-58.

Usman, H. (2015). The Role of Religious Norms on Selecting The Islamic Bank. AlIqtishad: Journal of Islamic Economics. Vol. 7 (1): 31-44.

Worthington, A.C. (2006). Predicting financial literacy in Australia. Financial Services Review, Vol. 15 No. 1: 59-79. 